\title{
H-bonding and Stacking Interactions between Chloroquine and Temozolomide
}

\author{
Okuma Emile Kasende* \\ Faculty of Science University of Kinshasa, \\ B.P. 190 Kinshasa XI, D. R. Congo \\ okuma.kasende@unikin.ac.cd \\ Vincent de Paul N. Nziko, Steve Scheiner* \\ Department of Chemistry \& Biochemistry Utah State University, \\ Logan, UT 84322-0300, USA \\ steve.scheiner@usu.edu
}

\begin{abstract}
The interactions between temozolomide and chloroquine were examined via DispersionCorrected Density Functional Theory and MP2 methods. Chloroquine was considered in both its lowest energy structure and in a local minimum where its aromatic system and secondary amine group are free to interact directly with temozolomide. The accessibility of these two components to intermolecular interaction makes the lowest energy dimer of this local monomer minimum competitive in total energy with that involving chloroquine's most stable monomer geometry. In either case, the most stable heterodimer places the aromatic ring systems of the two molecules parallel and directly above one another in a stacked geometry. Most of the local minima are also characterized by a stacked geometry as well. Comparison between B3LYP and B3LYP-D binding energies confirms dispersion is a primary factor in stabilizing these structures.
\end{abstract}

keywords: dispersion; NBO; AIM 


\section{Introduction}

Chloroquine (CQ) is commonly used in the treatment of malaria, a disease caused by infection with the parasite Plasmodium [1]. There are several decades of clinical experience with the use of CQ for the treatment of various parasitic and immune-mediated disorders, although its mechanism of action is still under investigation $[1,2]$. CQ, illustrated in Figure 1, is also reported as an antimutagenic with an optimal pharmacological profile for human use, and for treatment of patients with glioblastoma multiforme (GBM) [3, 4], the most frequent primary brain tumor in adults. Chronic administration of CQ greatly enhances the response of GBM to antineoplastic treatment, probably by virtue of its strong antimutagenic effect that precludes the appearance of resistant clones during therapy [5]. CQ may have the potential to open new frontiers in the treatment of glial neoplasms, because it has the unique features of well-studied side-effects, is inexpensive, and easily available. On the other hand, survival time in GBM patients has not increased substantially during the last few decades [6, 7], and treatment is complicated by acquired chemoresistance $[8,9]$.

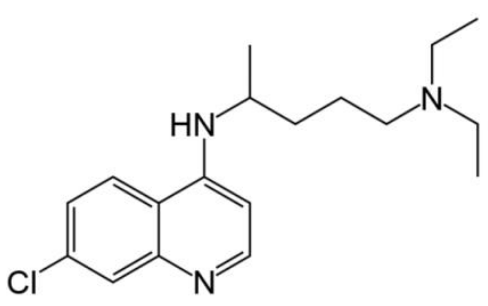

Figure 1. Structure of chloroquine (CQ)

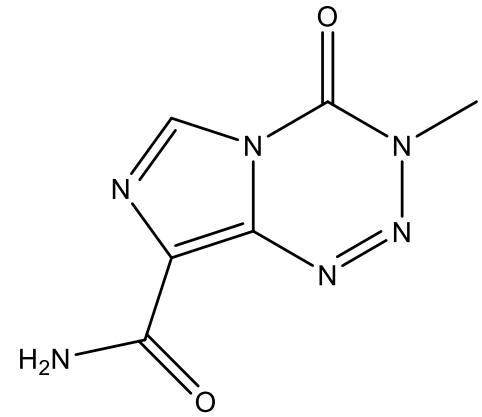

Figure 2. Structure of temozolomide (TMZ)

At the present time, temozolomide (TMZ; Figure 2) remains the main frontline treatment for GBM [10]. There are ongoing laboratory studies and clinical trials aimed to determine whether combining TMZ with other pharmacologic agents such as CQ might augment the anticancer potency of TMZ [11-13]. For example, the effects of CQ and TMZ on a mitochondrial reactive oxygen species indicator, and cell death examined in rat C6 glioma cells, has demonstrated that TMZ alone had little effect, but it increased mitochondrial cell death when administered in conjunction with CQ [14]. Nonetheless, the literature contains neither experimental nor 
theoretical work examining the direct interaction between TMZ and CQ.

There is of course the possibility that TMZ and CQ may work in tandem in a therapeutic context. Such joint effectiveness may result from the two molecules first combining with one another in a heterodimer. But even if this is not the case, the interaction between these two molecules represents an important and interesting case study. Each is characterized in part by a two-ring heteroaromatic system containing one or more $\mathrm{N}$ atoms. Appended to TMZ is an amide group, while CQ contains a longer aliphatic chain with two amine groups. There is a wide range of noncovalent interactions (NCI) that play roles in numerous biological processes [15-29], and a number of these can be envisioned as participating in the interaction. The amine and amide groups, for example, are well known to participate in H-bonds (HBs) as both donors and acceptors. The $\mathrm{Cl}$ atom on $\mathrm{CQ}$ can both accept a proton in a $\mathrm{HB}$ or act instead as electron acceptor in the context of a halogen bond. Moreover, planar aromatic systems such as those in CQ and TMZ are well known to act as HB acceptors, as well as engaging in $\pi-\pi$ stacking complexes. In this work, the various different sorts of noncovalent bonds are compared with one another as they compete to form any one of a number of different heterodimer geometries. As described below, quantum calculations suggest that the most stable dimers are not necessarily those with only one particular sort of bond, but rather allow them to coexist with one another so as to stabilize the system.

\section{Computational Methods}

The flexibility of the alkyl chain of CQ leads to quite a large number of different rotamers to be considered as starting guesses for its global minimum. A search for the optimal geometry began with a scan of the surface wherein five different dihedral angles were incremented between $0^{\circ}$ and $360^{\circ}$ in $10^{\circ}$ increments. The global minimum is illustrated in Fig 3 as CQA, and is stabilized in part by a $\mathrm{NH} \cdot \cdot \mathrm{N}$ HB of length $1.939 \AA$. This geometry places the tertiary amine group directly over the aromatic system. A second minimum on the CQ surface was considered where the amine does not block either side of the aromatic region. CQB in Fig 3 is a local minimum on the CQ surface, $24.1 \mathrm{~kJ} / \mathrm{mol}$ higher in energy than CQA. Unlike CQ, TMZ has only two plausible rotamers which depends upon the orientation of the amide group. The more stable of the two, lower in free energy at the G3MP2 level by $5.5 \mathrm{~kJ} / \mathrm{mol}$ [30], corresponds to the geometry in Fig 2. 
The geometries of TMZ-CQA and TMZ-CQB complexes were fully optimized using the M06-2X/6-31+G(d,p) protocol. Vibrational analysis verified each structure as a true minimum. Single point calculations of these CQ-TMZ heterodimers were carried out using both DFT and wave function methods, namely, B3LYP, B3LYP-D3, M06-2X, $\omega$ B97XD and MP2 protocols, all with the $6-31+\mathrm{G}(\mathrm{d}, \mathrm{p})$ basis set [31-41]. 100 random geometries generated by a home program (Department of Chemistry and Biochemistry, Utah state University, USA) were taken as starting points, leading to 11 distinct TMZ-CQA and TMZ-CQB dimer geometries. The binding energy, $\mathrm{BE}$, of each complex was computed as the difference in energy between the optimized dimer and the sum of the monomers in their optimized geometries. This binding energy was corrected for basis set superposition error (BSSE) [42] using the Boys-Bernardi counterpoise correction [43].

The dispersion energy was estimated as the difference in binding energy between B3LYP-D3 and B3LYP as described by Equation (1). The molecular electronic energies E were computed by dispersion-corrected DFT given by Equation (2), in which $\mathrm{E}_{\mathrm{DFT}}$ is the (all-electron) KS-DFT SCF energy for a particular density functional, $\mathrm{E}^{(2)}$ disp is the standard atom pair-wise London dispersion energy from D3 theory [44] (using Becke-Johnson damping [45-47]), and $\mathrm{E}^{(3)}$ disp is a three-body dispersion term (of Axilrod-Teller-Mutto type $[48,49]$ ), which was calculated as described in reference [47] using the DFT-D3 program [50].

$$
\begin{aligned}
& \mathrm{DISP}=\mathrm{BE}_{(\mathrm{B} 3 \mathrm{LYP}-\mathrm{D} 3)}-\mathrm{BE}_{(\mathrm{B} 3 \mathrm{LYP})} \\
& \mathrm{E}_{\mathrm{B} 3 \mathrm{LYP}-\mathrm{D}}=\mathrm{E}_{\mathrm{DFT}}+\mathrm{E}^{(2)}{ }_{\text {disp }}+\mathrm{E}^{(3)}{ }_{\text {disp }}
\end{aligned}
$$

Calculations were performed using the Gaussian 09 software package [51,52]. Atomic charges and charge transfer energies were assessed by the NBO 6.0 program [53]. GaussView and Chemcraft programs were used for visualization [54]. The atoms in molecule (AIM) procedure [54,55] was employed to determine the position of the bond critical points, as well as their density using the AIMALL software [56], at the M062x/6-31+G**/6-31+G** level. 


\section{Results}

The three most stable heterodimer structures of TMZ with CQA and CQB are illustrated in Figs 4 and 5, respectively; the remaining dimers are displayed in the Supporting Information. The binding energies of TMZ-CQA and TMZ-CQB are reported in Table 1 and Table 2 for three levels of theory. A fourth level, $\omega$ B97XD, was added in the case of TMZ-CQA in Table 1 to help resolve energy ordering as some of the structures are clustered close together. The structures are numbered in descending order of binding energy computed at the M06-2X level. Also reported in Tables 1 and 2 are those NBO charge transfer energies E(2) which attain the threshold of $2 \mathrm{~kJ} / \mathrm{mol}$. The dimers TMZ-CQA are denoted A and the B prefix is used for TMZCQB. The atomic numbering system is described in Fig. 3.

TMZ-CQA dimers

The 11 minima fall into one of two categories. The aromatic systems are either stacked one above the other or are perpendicular, in a sort of T-shape; no coplanar dimer was observed. Three of the four methods place A1, A2, and A3 as the three most stable structures; $\omega \mathrm{B} 97 \mathrm{XD}$ finds A4 to be more stable than A2. All of these structures are of the stacked category. The binding energies are in the 55-61 kJ/mol range for M06-2X and $\omega$ B97XD. B3LYP-D3 quantities are somewhat smaller, and MP2 smaller still, between 37 and $40 \mathrm{~kJ} / \mathrm{mol}$. Three of the four methods place A1 as the most stable, even if only by a small margin. NBO analysis of A1 indicates a fairly strong $\mathrm{CH} \cdot \cdot \mathrm{O} \mathrm{HB}$, with $\mathrm{R}(\mathrm{H} \cdot \mathrm{O})=2.31 \AA$ and $\mathrm{E}(2)=14.2 \mathrm{~kJ} / \mathrm{mol}$. There is also present a much longer and weaker $\mathrm{CH} \cdot \mathrm{Cl} \mathrm{HB}$. The other NBO charge transfers are primarily of the ring $\rightarrow$ ring $\pi \rightarrow \pi^{*}$ type. A2 has a larger number of HBs: both $\mathrm{CH} \cdot \cdot \mathrm{O}$ and $\mathrm{CH} \cdot \cdot \mathrm{N}$, but none of these have a $\mathrm{E}(2)$ above $5 \mathrm{~kJ} / \mathrm{mol}$. There are no identifiable HBs at all in A3, with all its NBO charge transfers associated instead with $\pi \rightarrow \pi^{*}$.

Given the small cumulative NBO E(2) in these complexes, in comparison with their overall large binding energy, coupled with their stacked geometries, it is logical to presume that dispersion makes a large contribution to these complexes. One can take the difference between the standard B3LYP and B3LYP-D3 binding energies as a rough measure of dispersion since the latter was designed so as to explicitly evaluate the dispersion energy that is not contained within the original B3LYP formalism. These binding energies are displayed in Table 3 for all 11 of the A dimers, and their difference reported in the last column. The large negative quantities in the final column emphasize the importance of dispersion in these complexes, rising up to nearly 100 
$\mathrm{kJ} / \mathrm{mol}$. Indeed, it is instructive to note from the positive values in the B3LYP column that none of these structures are bound at all without explicit inclusion of dispersion. This large contribution is true not only for the stacked geometries but also for T-shaped structures A4, A5, A6, A10, and A11.

Another perspective on the nature of the bonding is gleaned from the manner in which electron density is shifted when the two monomers interact with one another. The electron density shift (EDS) map of Fig 6 was constructed by subtracting the sum of the densities of the two unperturbed monomers from that of the density of the entire A1 dimer. The blue regions represent gains of density and losses are indicated by red. The most prominent feature of this map is the blue gain of density around the carbonyl $\mathrm{O}$ of TMZ and the red loss surrounding the $\mathrm{H}$-bonding $\mathrm{CH}$ proton. This pattern is characteristic of HBs and further verifies the presence of this $\mathrm{CH} \cdot \mathrm{O} \mathrm{HB}$, already suggested by both geometry and NBO charge transfer. The shifts associated with the secondary $\mathrm{CH} \cdot \cdot \mathrm{Cl} \mathrm{HB}$ are smaller, consistent with the weaker nature of this HB. They consequently only appear if a larger threshold of the contour displayed is employed. Note that there are few large scale density shifts associated with the strong interaction between the two aromatic systems. These weak changes are due primarily to the nature of dispersive forces, reinforced by the relatively small $\pi \rightarrow \pi^{*}$ charge transfers reported in Table 1 .

With respect to the Coulombic component of the attraction between the two molecules, one would anticipate that any positive regions of one molecule would be attracted toward negative areas of its partner and vice versa. The molecular electrostatic potential (MEP) that surrounds each monomer is displayed in Fig 7, wherein blue/red indicates positive/negative potential. It is first clear that the two $\mathrm{O}$ atoms of TMZ are most negatively charged, as is the CQ N atom of its pyridine ring. Despite its electronegativity, the $\mathrm{Cl}$ atom does not induce a substantial negative potential in its vicinity. There are positive areas in CQA but these are not as intense as those within TMZ. Focusing on the aromatic segments, TMZ contains much more positive areas, particularly above its six-membered ring, compared to CQA which has no strongly positive regions around its aromatic section. And with the exception of the pyridine $\mathrm{N}$ atom, CQA has little in the way of highly negative areas either. One might therefore conclude that the attraction seen between the aromatic segments of the two molecules is clearly not dominated by electrostatic attraction. 


\section{$\underline{\text { TMZ-CQB dimers }}$}

As indicated above, it is worthwhile to examine more than a single conformation of a very flexible molecule like CQ. Since the global minimum places the tertiary amine group directly above the aromatic system, a second minimum on the surface where this is not the case was considered as well. CQB lies some $21 \mathrm{~kJ} / \mathrm{mol}$ higher in energy than CQA, due in part to the loss of CQA's intramolecular $\mathrm{NH} \cdot \mathrm{N}$ HB. On the other hand, this second conformation could be competitive with the global minimum, or perhaps even more stable, in a H-bonding solvent which would compete with the internal HB of CQA. But again, even if not the most stable geometry of the monomer, it is of some interest to examine the ability of an alternate structure to engage in an intermolecular complex with a molecule like TMZ. Indeed, the value of this exercise is underscored below.

And indeed, one sees some intriguing differences in the complexes formed by CQA and CQB. There is a greater extent of strong H-bonding in the complexes of the latter conformation with TMZ. As is evident in Fig 5 there are 3 such bonds in the most stable B1, one of which is shorter than $2.1 \AA$. There are 5 HBs in B2, two of which are shorter than $2.2 \AA$, and 4 such bonds in B3. A glance at Table 2 reinforces the idea gleaned from geometries that the HBs are considerably stronger for CQB complexes than for CQA. E(2) for the major $\mathrm{NH} \cdot \mathrm{O} \mathrm{HB}$ in $\mathrm{B} 1$ is $32 \mathrm{~kJ} / \mathrm{mol}$; B2 contains a $\mathrm{NH} \cdot \cdot \mathrm{N}$ HB with $\mathrm{E}(2)=82 \mathrm{~kJ} / \mathrm{mol}$ and a $\mathrm{NH} \cdot \mathrm{O} \mathrm{HB}$ for which $\mathrm{E}(2)$ is 54 $\mathrm{kJ} / \mathrm{mol}$. In fact, a survey of Table 2 shows that there is at least one HB in every one of the 11 complexes formed by CQB. For example, Fig 5 shows that the latter HB has length 2.096, 2.146, and $2.036 \AA$ in B1, B2, and B3, respectively. These HBs make for considerably stronger binding. CQB is bound to TMZ in B1 by some $80 \mathrm{~kJ} / \mathrm{mol}$, compared to only some $50-60 \mathrm{~kJ} / \mathrm{mol}$ for the A1 minimum.

It is this prevalence of strong HBs that allow some of the B dimers to be competitive in total energy with the A dimers even though the latter incorporate the considerably more stable CQA monomer. That is, although CQA monomer is preferred over CQB largely by virtue of its internal $\mathrm{NH} \cdot \mathrm{N} \mathrm{HB}$, this same $\mathrm{HB}$ acts to hinder the formation of the even stronger $\mathrm{NH} \cdot \cdot \mathrm{O} \mathrm{HB}$ with the carbonyl $\mathrm{O}$ atom of TMZ, which preferentially stabilizes the B dimers. The energy of each of these B dimers, relative to the most stable A1 CQA-TMZ dimer, is reported in italics in Table 3. B1, for example, is some $9.5 \mathrm{~kJ} / \mathrm{mol}$ more stable than A1 at the B3LYP-D3 level; this margin is reduced to $0.16 \mathrm{~kJ} / \mathrm{mol}$ at MP2. Both of these levels of theory would therefore deem 
B1 the global minimum. M06-2X, on the other hand, retains the lower energy of A1 vs B1, although by only $3 \mathrm{~kJ} / \mathrm{mol}$. B3LYP-D3 even has B2 more stable than A1. One thus arrives at the important conclusion that the energetically favored structure of the monomer does not necessarily lead to more stable dimers.

Considering the B dimers individually, B1 is clearly the most stable, with a binding energy exceeding $80 \mathrm{~kJ} / \mathrm{mol}$, some $7-28 \mathrm{~kJ} / \mathrm{mol}$ lower in energy than the next most stable B2. NBO identifies a $\mathrm{NH} \cdot \mathrm{O}$ HB as the dominant specific interaction, with $\mathrm{E}(2)=38.36 \mathrm{~kJ} / \mathrm{mol}$. This $\mathrm{HB}$ is only $2.096 \AA$ in length, as depicted in Fig 5 , and is close to linear with a $\theta(\mathrm{NH} \cdot \mathrm{O})$ angle of $160^{\circ}$. A much weaker $\mathrm{CH} \cdot \cdot \mathrm{N} \mathrm{HB}$ with $\mathrm{E}(2)=5.14 \mathrm{~kJ} / \mathrm{mol}$ is indicated by $\mathrm{NBO}$, considerably longer at $2.554 \AA$. The greater strength of the former HB is verified by the density at the AIM bond critical point $(0.184 \mathrm{au})$ which exceeds that of the latter by a factor of three. There is an even weaker $\mathrm{CH} \cdot \odot \mathrm{O}$ HB present in $\mathrm{B} 1$, with $\mathrm{E}(2)$ only $2.8 \mathrm{~kJ} / \mathrm{mol}$.

The second most stable structure $\mathrm{B} 2$ contains a pair of quite strong $\mathrm{HBs}, \mathrm{NH} \cdot{ }^{\circ} \mathrm{N}$ and $\mathrm{NH} \cdot{ }^{\circ} \mathrm{O}$, and both shorter than $2.2 \AA$. Moreover, the $\mathrm{E}(2)$ values are quite large, 81.59 and $53.8 \mathrm{~kJ} / \mathrm{mol}$, respectively. The stability of $\mathrm{B} 2$ is further reinforced by several weaker $\mathrm{CH} \cdot \mathrm{X}$ HBs, with $\mathrm{E}(2)$ in the 3.97-6.28 kJ/mol range. Despite this assortment of HBs, two of them quite strong, B2 is less stable than B1, a point which is discussed in some detail below. B3 is similar to B1 in containing one $\mathrm{NH} \cdot \mathrm{O}$ HB which is in this case weaker, with $\mathrm{E}(2)=24.02 \mathrm{~kJ} / \mathrm{mol}$, supplemented by weaker $\mathrm{CH} \cdot \mathrm{X} \mathrm{HBs}$, but is considerably less stable. Progressing further down Table 2, one sees evidence of HBs in each configuration, but the energetic ordering is only partially related to the number and strength of these HBs. The two least stable configurations also contain evidence of a halogen bond involving the $\mathrm{Cl}$ atom and a $\mathrm{N}$ receptor atom.

In addition to the HBs indicated by $\mathrm{E}(2)$ in Table 2, there are a number of other charge transfers. For example, B1 exhibits $\pi(\mathrm{CC}) \rightarrow \pi^{*}(\mathrm{CC})$ and $\pi(\mathrm{CC}) \rightarrow \sigma^{*}(\mathrm{CC})$ transfers between the rings of the two molecules. Likewise there is a $\pi(\mathrm{CC}) \rightarrow \pi^{*}(\mathrm{CO})$ transfer indicated for B4. These two configurations are unique amongst the 11 minima in that they can be described as a stacked structure wherein the two rings lie right above, and approximately parallel to one another. Such an arrangement is conducive to a particularly large dispersion attractive force. This sort of attraction does not show up easily in an NBO analysis, which focuses on charge transfer. As above, the contribution of dispersion was estimated by comparison of the B3LYP and B3LYP- 
D3 binding energies, and the data are compiled in Table 4. It may immediately be noted that the stacked B1 and B4 geometries are characterized by a considerably larger dispersion attraction $\triangle \mathrm{BE}$ than the other structures. That is, the dispersion energies of B1 and B4 are respectively 80 and $72 \mathrm{~kJ} / \mathrm{mol}$, while the others are much smaller, some less than $10 \mathrm{~kJ} / \mathrm{mol}$. It is interesting to note that B4 is not bound at all when dispersion is not included, with a negative B3LYP binding energy. The four most weakly bound dimers, B8-B11, all contain less than $20 \mathrm{~kJ} / \mathrm{mol}$ of dispersion energy.

In summary, then, the strengths of the various dimers can be thought of as deriving from two principal attractive forces. H-bond strength is an important phenomenon, which may be assessed indirectly via NBO charge transfers, as well as geometric characteristics. But dispersion also plays a major role, adding special stabilization to the two stacked structures. In fact, the global minimum is of the stacked variety, supplemented by several HBs, only one of which is a strong one.

In the EDS map of the dimer B1 depicted in Figure 8, the green regions represent gains of density and losses are indicated by yellow. This map is consistent with the NBO identification of three HBs. A HB is characteristically revealed by a (yellow) loss of density around the bridging proton and a corresponding (green) gain in the vicinity of the lone pair of the protonaccepting atom. The three HBs of Fig 8 all display this fingerprint pattern. Moreover, the size of the green/yellow regions for each HB are consistent with the NBO value of E(2) in Table 2, as well as the HB lengths of Fig 5 . The $\pi \rightarrow \pi^{*}$ and $\pi \rightarrow \sigma^{*}$ transfers indicated in Table 2 are not clearly visible in Fig 8. However, shifts between the two $\pi$-systems do appear when the contour represented is reduced from the 0.0015 au of Fig 8 to a smaller threshold.

Turning to AIM analysis of the electron density, there are five bond paths present between the two monomers within B1. Two of these bond paths correspond to the $\mathrm{NH} \cdot \mathrm{O}$ and $\mathrm{CH} \cdot \mathrm{N}$ HBs predicted by NBO, with HB lengths of 2.096 and $2.555 \AA$, respectively. According to a relationship in the literature between $\mathrm{HB}$ energy $\mathrm{E}_{H B}$ and potential energy density $\mathrm{V}(\mathrm{r})$ at the corresponding $\mathrm{BCP}\left(\mathrm{E}_{H B}=\mathrm{V}(\mathrm{r})_{\mathrm{BCP}} / 2\right)$ [57], the $\mathrm{E}_{H B}$ of the $\mathrm{H} \cdots \mathrm{O} H B$ in this stacked dimer is $19.44 \mathrm{~kJ} / \mathrm{mol}$. Another BCP of weak potential energy density between $\mathrm{N}_{12}$ and $\mathrm{H}_{64}$ atoms suggests a weak $\mathrm{N} \cdots \mathrm{H}$ HB for which the $\mathrm{E}_{H B}$ is approximated as $5.07 \mathrm{~kJ} / \mathrm{mol}$. Cumulatively, these two HBs total $24.51 \mathrm{~kJ} / \mathrm{mol}$, or $30 \%$ of the total binding energy. 
On the other hand, AIM shows no indication of the $\mathrm{CH} \cdot \cdot \mathrm{O}$ HB in Fig 5. The $\mathrm{NBO}_{49-}$ $\mathrm{C}_{57}(\pi) \rightarrow \mathrm{C}_{1}-\mathrm{C}_{3}\left(\sigma^{*}\right)$ and $\mathrm{C}_{10}-\mathrm{C}_{11}(\pi) \rightarrow \mathrm{C}_{49}-\mathrm{C}_{57}\left(\pi^{*}\right)$ charge transfers appear to coalesce into a related $\mathrm{C}_{49}-\mathrm{C}_{57} \cdots \mathrm{C}_{3}-\mathrm{C}_{10}$ bond via AIM. On the other hand, there is no AIM correlate of the $\mathrm{N}_{12}-$ $\mathrm{C}_{13}(\pi) \rightarrow \mathrm{C}_{56}-\mathrm{H}_{64}\left(\sigma^{*}\right)$ NBO transfer, suggesting instead $\mathrm{C}_{1}-\mathrm{C}_{3} \cdots \mathrm{N}_{60}-\mathrm{C}_{58}$ and $\mathrm{C}_{6}-\mathrm{C}_{11} \cdots \mathrm{N}_{51}$ bond paths. Disagreements of this sort between AIM and NBO are not uncommon [58-64], as they represent alternate views of the bonding.

\section{Discussion}

Extensive search of the potential energy surface of the TMZ/CQ heterodimer led to a large number of minima. Within the context of the global minimum of the CQ monomer, CQA, 11 different minima were identified; a like number of dimers were found for a different CQ monomer CQB where the tertiary amine group does not obstruct the aromatic system. The most stable of these dimers are stacked in that the aromatic systems of the two molecules are nearly parallel, lying directly above one another. The stability of this mode of binding derives from two primary factors. There are $\mathrm{HBs}$ present: some are strong e.g. $\mathrm{NH} \cdot \mathrm{O}$ but others considerably weaker as in $\mathrm{CH} \cdot \cdot \mathrm{O}$ and $\mathrm{CH} \cdot \cdot \mathrm{Cl}$. Another major contributor is dispersion attraction between the two molecules. There is a clear margin separating stacked geometries from unstacked structures which are stabilized by several stronger $\mathrm{HBs}$, particularly $\mathrm{NH} \cdot \cdot \mathrm{N}$ and $\mathrm{NH} \cdot \cdot \mathrm{O}$.

The importance of dispersion in stacking interactions of this sort is supported by a wealth of prior observations [74-80]. The tendency of TMZ toward a stacked arrangement is not unique to its interaction with chloroquinone. A recent examination of all possible geometries of the TMZ homodimer identified [81] a stacked structure as preferable to coplanar geometries. This finding is particularly notable since, unlike the TMZ-CQ heterodimer where one can identify a number of HBs that contribute to the stability, the stacked TMZ homodimer is nearly free of the latter forces, relying almost entirely on $\pi \rightarrow \pi^{*}$ charge transfers between the aromatic systems, as well as dispersive forces.

The partial obstruction of the aromatic system by the tertiary amine in the global minimum of CQ reduces the interaction with TMZ. The other factor is the prior involvement of CQA's secondary amine $\mathrm{NH}$ in an intramolecular $\mathrm{HB}$, preventing it from engaging in a $\mathrm{HB}$ with any of the proton acceptor sites of TMZ. For example, TMZ is bound to this global CQA minimum by less than $60 \mathrm{~kJ} / \mathrm{mol}$, compared to a binding energy in excess of $80 \mathrm{~kJ} / \mathrm{mol}$ when the amine is displaced away from the aromatic system in CQB and the secondary amine $\mathrm{NH}$ is available for 
H-bonding. Thus, the latter strongly bound complex is lower in total energy than is the structure involving the global minimum of CQA monomer, despite the more than $20 \mathrm{~kJ} / \mathrm{mol}$ energetic preference of the CQA monomer over CQB. The global minimum of the dimer is stabilized not only by strong dispersion forces between the parallel rings, but also by a strong intermolecular $\mathrm{NH} \cdot \mathrm{O}$ HB. This observation is consistent with previous reports [65-73] that attribute the noncovalent bonding preferences of the TMZ molecule to its terminal amide group.

The dispersion energies computed here for these dimers are rather large, particularly for the stacked geometries where they can approach $100 \mathrm{~kJ} / \mathrm{mol}$. While the interaction between the two aromatic systems is responsible for a large part of this dispersion, one cannot completely ignore interactions between TMZ and the fairly long pendant alkyl chain of CQ. For example, removal of the latter segment from CQ reduces the dispersion energy in the A1 dimer from 86 to 69 $\mathrm{kJ} / \mathrm{mol}$. One can conclude that the aromatic interaction accounts for a majority, in this case $80 \%$, of the total dispersion energy.

This quantity can be compared to the dispersion energy in the stacked dimer of benzene, computed to be $25 \mathrm{~kJ} / \mathrm{mol}$ at the same level of theory. In fact, the accuracy of estimating the dispersion energy as the difference between B3LYP-D3 and B3LYP is confirmed by a more rigorous assessment, derived from Symmetry-Adapted Perturbation Theory (SAPT) [82], which yields a dispersion energy for the same benzene dimer of $28 \mathrm{~kJ} / \mathrm{mol}$. The greater magnitude of the quantity associated with the CQ-TMZ dimer is easily reconciled with the much larger aromatic systems in each molecule, compared to a single six-membered ring.

In conclusion, chloroquine and temozolomide engage in a number of different heterodimer geometries. The driving force for the most stable structures is a dispersion-dominated attraction between the aromatic systems of the two molecules. Some of the dimers are supplemented by Hbonds, particularly if the strong intramolecular $\mathrm{NH} \cdot \cdot \mathrm{N} \mathrm{HB}$ within CQ is broken, leaving the two groups available for formation of intermolecular HBs.

\section{Acknowledgments}

O.E.K. would like to thank the Council for International Exchange of Scholars (CIES) for a Fulbright Visiting Scholar grant at Utah State University. Computer, storage and other resources from the Division of Research Computing in the Office of Research and Graduate Studies at Utah State University are gratefully acknowledged. 


\section{Supporting Information}

Geometries of the least stable eight optimized complexes of both the CQA and CQB

heterodimers are illustrated in Figs S1 and S2 of the Supporting Information, respectively. Also included are the cartesian coordinates of all dimers. 


\section{References}

[1] M. Schlitzer, Chem. Med. Chem. 2007, 2, 944.

[2] A.G. Finesilver, WMJ. 2003, 102, 34.

[3] J. Sotelo, E. Briceno, M.A. Lopez-Gonzalez, Ann. Intern. Med. 2006, 144, 337.

[4] E. Briceno, A. Calderon, J. Sotelo, Surg. Neurol. 2007, 67, 388.

[5] E. Briceño, S. Reyes, J. Sotelo, Neurosurg. Focus 2003,14, 1.

[6] A. Flowers, V.A. Levin, Chemotherapy for brain tumors, in Brain Tumors: An Encyclopedic Approach, ed 2; A.H. Kaye, E.R. Laws Jr (eds): London: Churchill Livingstone, 2001.

[7] H.B. Newton, Expert Opin. Investig. Drugs 2000, 9, 2815.

[8] M. Bredel, Brain Res. Rev. 2001, 35, 161.

[9] L.G. Feun, N. Savaraj, H.J. Landy, J. Neurooncol. 1994, 20, 165.

[10] H.S. Friedman, T. Kerby, H. Calvert, Clin. Cancer Res. 2000, 6, 2285.

[11] F.V. Jacinto, M. Esteller, DNA Repair 2007, 6:1155-1160

[12] M.R. Gilbert, Ann. Intern. Med. 2006, 144, 371.

[13] S.W. Lee SW, H.K. Kim, N.H. Lee, H.Y. Yi, H.S. Kim, S.H. Hong, Y.K. Hong, Y.A. Joe. Cancer Letters 2015, 360, 195

[14] Y. Hori, R. Hosoda, Y. Akiyama, R. Sebori, M. Wanibuchi, T. Mikami, T. Sugino, K. Suzuki, M. Maruyama, M. Tsukamoto, N. Mikuni, Y. Horio, A. Kuno, J. Neurooncol. 2015, 122, 11.

[15] P. Hobza, K. Müller-Dethlefs, Non-Covalent Interactions: Theory and Experiment; Royal Society of Chemistry: Cambridge UK, 2010.

[16] A. Karshikoff, Non-Covalent Interactions in Protein; World Scientific: London, 2006.

[17] S. Scheiner, Noncovalent Forces; Springer: Switzland, 2015.

[18] A.M. Maharramov, K.T. Mahmudov, M.N. Kopylovich, A.J.L. Pombeiro, Non-covalent Interactions in the Synthesis and Design of New Compounds; Wiley, 2016.

[19] H. Lodish, Molecular Cell Biology; 4th edition W.H. Freeman: New York USA, 2000.

[20] P. Schuster, G. Zundel, C. Sandorfy (Eds.), The hydrogen bond, Recent Developments in Theory and Experiments; North-Holland Publishing Co: Amsterdam, 1976.

[21] P. Schuster, Hydrogen Bonds; Springer-Verlag: Berlin, 1984.

[22] G.A. Jeffrey, W. Saenger, Hydrogen Bonding in Biological Structures; Springer-Verlag: Berlin, 1991

[23] S. Scheiner, Hydrogen Bonding. A Theoretical Perspective; Oxford University Press: New York, 1997.

[24] G. Gilli, P. Gilli P, The Nature of the Hydrogen Bond; Oxford University Press: Oxford, 2009.

[25] R. Wieczorek, J.J. Dannenberg, J. Am. Chem. Soc. 2003, 125, 8124.

[26] I.V. Alabugin, M. Manoharan, S. Peabody, F. Weinhold, J. Am. Chem. Soc. 2003, 125, 5973.

[27] H. Hernández-Soto, F. Weinhold, J.S. Francisco, J. Chem. Phys. 2007, 127, 64102. 
[28] J.E. DelBene, I. Alkorta, J. Elguero, Phys. Chem. Chem. Phys. 2011,13, 13951.

[29] T.S. Thakur, M.T. Kirchner, D. Blaser, R. Boese, G.R. Desiraju, Phys. Chem. Chem. Phys. 2011, 13, 14076.

[30] S. Mirzaei, M. H. Khalilian, A. A. Taherpour, RSC Adv., 2015, 5, 41112

[31] C.T. Lee, W. Yang, R.G. Parr, Phys. Rev. 1988, B37, 785.

[32] A.D. Becke, J. Chem. Phys. 1993, 98, 5648.

[33] S. Grimme, Density functional theory with London dispersion corrections. WIREs

Computational Molecular Science; John Wiley \& Sons Ltd, 2011.

[34] Y. Zhao, D.G. Truhlar, Theor. Chem. Account 2008, 120, 215.

[35] M, Walker, A.J.A. Harvey, A. Sen, C.E.H. Dessent, J. Phys. Chem. A 2013, 117, 12590.

[36] A.J. Cohen, P. Mori-Sánchez, W. Yang, Chemical Reviews 2012, 112, 289.

[37] E.G. Hohenstein, S.T. Chill, C.D. Sherrill, J. Chem. Theor. Comput. 2008, 4, 1996.

[38] K.E. Riley, M. Pitoňák, P. Jurečka, P. Hobza, Chem. Rev. 2010, 110, 5023.

[39] L. Ferrighi, Y. Pan, H. Grönbeck, B. Hammer, J. Phys. Chem. 2012, 116, 7374.

[40] J.D. Chai, M. Head, Phys. Chem. Chem. Phys. 2008, 10, 6615.

[41] G.A. DiLabio, E.R. Johnson, A. Otero-de-la-Roza, Phys. Chem. Chem. Phys. 2013, 15, 12821.

[42] M. Gutowski, J.G.C.M. van Duijneveldt van de Rijdt, J.H. van Lenthe, F.B. van

Duijneveldt, J. Chem. Phys. 1993, 98, 4728.

[43] S.F. Boys, F. Bernardi, Mol. Phys. 1970, 19, 553.

[44] S. Grimme, J. Antony, S. Ehrlich, H. Krieg, J. Chem. Phys. 2010, 132, 154104.

[45] S. Grimme, S. Ehrlich, L. Goerigk, J. Comput. Chem. 2011, 32, 1456.

[46] A.D. Becke, E.R. Johnson, J. Chem. Phys. 2005, 122, 154104.

[47] E.R. Johnson, A.D. Becke, J. Chem. Phys. 2005, 123, 024101

[48] B.M. Axilrod, E. Teller, J. Chem. Phys. 1943, 11, 299.

[49] J. Mutto, Proc. Phys. Math. Soc. Japan, 1943, 17, 629.

[50] See http://www.thch.uni-bonn.de/.

[51] R. Dennington, T. Keith, J. Millan, GaussView, version 5, Semichem. Inc., Shawnee Mission, KS 2009.

[52] M.J. Frisch, G.W. Trucks, H.B. Schlegel, G.E. Scuseria, M.A. Robb, J.R. Cheeseman, G. Scalmani, V. Barone, B. Mennucci, G.A. Petersson et al., Gaussian 09, revision A.02, Gaussian Inc., Wallingford, CT 2009.

[53] E.D. Glendening, J.K. Badenhoop, A.E. Reed, J.E. Carpenter, J.A. Bohmann, C.M. Morales, C.R. Landis, F. Weinhold NBO 6.0. Theoretical Chemistry Institute, University of Wisconsin, Madison 2013.

[54] R.F.W. Bader, Atoms in Molecules, A Quantum Theory; Clarendon Press: Oxford, UK, 1990

[55] M.T. Carroll, C. Chang, M.F.W. Bader, Mol. Phys. 1988, 63, 387.

[56] T.A. Keith, AIMALL, TK Gristmill Software: Overland Park, KS 2013.

[57] E. Espinosa, E. Molins, C. Lecomte C, Chem Phys Lett 1998, 285, 170. 
[58] J. Poater, M. Solà, F.M. Bickelhaupt, Chem. Eur. J. 2006, 12, 2902.

[59] C. Foroutan-Nejad, S. Shahbazian, R. Marek, Chem. Eur. J. 2014, 20, 10140.

[60] I. Alkorta, G. Sanchez-Sanz, J. Phys. Chem. A 2014, 118, 1527.

[61] L.M. Azofra, S. Scheiner, Phys. Chem. Chem. Phys. 2014, 16, 5142.

[62] E.R. Johnson, S. Keinan, P. Mori-Sanchez, J. Contreras-Garcia, A.J. Cohen, W.Yang, J. Am. Chem. Soc. 2010, 132, 6498.

[63] M. Jablonski, M. Palusiak, Chem. Phys. 2013, 415, 207.

[64] L.M. Azofra, S. Scheiner, J. Chem. Phys. 2014, 140, 034302.

[65] Q. Bhat, S. Ahmad, J. Mol. Struct. 2015, 1099, 453.

[66] O.E. Kasende, A. Matondo, M. Muzomwe, J.T. Muya, S. Scheiner, Comput. Theor. Chem. 2014, 1034, 26.

[67] O.E. Kasende, J.T. Muya, S. Scheiner, Structural Chemistry 2015, 26, 1359.

[68] O.E. Kasende, A. Matondo, J.T. Muya, S. Scheiner, Comput. Theor. Chem., 2016, 1085, 82.

[69] P. Galek, E. Pidcock, P. Wood, CCDC, CSD Solid Form Suite, <http:// www.ccdc.cam.ac.uk/products/csd_solid_form_suite> 2011

[70] P.R. Lowe, C.E. Sansom, C.H. Schwalbe, M.F. Stevens, A.S. Clark, J. Med. Chem. 1992, $35,3377$.

[71] N.J. Babu, P. Sanphui, A. Nangia, Chem. Asian J. 2012, 7, 2274.

[72] N.J. Babu, S. Sanphui, N.K. Nath, U.B.R. Khandavilli, A. Nangia, Cryst Eng Comm. 2013, 15, 666.

[73] A.D. Becke, J. Chem. Phys. 1993, 98, 5648.

[74] L. Yang, J.B. Brazier, T.A. Hubbard, D.M. Rogers, S.L. Cockroft, Can Dispersion Forces Govern Aromatic Stacking in an Organic Solvent? Angew. Chem. Int. Ed.. 2016.

[75] S. Dev, K. Giri, M. Majumder, N. Sathyamurthy, Mol. Phys. 2015, 113, 2952.

[76] S.A. Reid, S. Nyambo, L. Muzangwa, B. Uhler, J. Phys. Chem. A 2013, 117, 13556.

[77] W. Wang, Y. Zhang, Y. Wang, Comput. Theor. Chem. 2013, 1023, 88.

[78] S. Kumar, A. Das, J. Chem. Phys. 2013, 139, 104311.

[79] F. Cozzi, M. Cinquini, R. Annuziata, J.S. Siegel, J. Am. Chem. Soc. 1993, 115, 5330.

[80] R. Leist, J.A. Frey, S. Leutwyler, J. Phys. Chem. A 2006, 110, 4180.

[81] O.E. Kasende, J.T. Muya, V. de P. Nziko, S. Scheiner, J. Mol. Mod. 2016, $22,77$.

[82] H.-J. Werner, P. J. Knowles, G. Knizia, F. R.Manby, M. Schütz, Wiley Interdisciplinary Reviews: Computational Molecular Science 2012, 2, 242. 
Table 1. Binding energies BE and NBO second-order perturbation energies E(2) for CQATMZ complexes calculated with the $6-31+\mathrm{G}^{* *}$ basis set, all in $\mathrm{kJ} / \mathrm{mol}$

\begin{tabular}{|c|c|c|c|c|c|c|}
\hline Dimer & \multicolumn{4}{|c|}{$\mathrm{BE}$} & \multirow[b]{2}{*}{ CQA... TMZ } & \multirow[t]{2}{*}{ NBO E(2) } \\
\hline & M062X & $\omega B 97 X D$ & B3LYP-D3 & MP2 & & \\
\hline A 1 & -58.70 & -57.80 & -48.55 & -40.68 & $\begin{array}{l}\mathrm{C}_{27}-\mathrm{H}_{29}\left(\sigma^{*}\right) \leftarrow \mathrm{O}_{62}(\mathrm{LPs}) \\
\mathrm{N}_{12}-\mathrm{C}_{13}\left(\pi^{*}\right) \leftarrow \mathrm{C}_{49}-\mathrm{C}_{57}(\pi) \\
\mathrm{C}_{2}-\mathrm{C}_{6}(\pi) \rightarrow \mathrm{C}_{50}-\mathrm{O}_{55}\left(\pi^{*}\right) \\
\mathrm{C}_{9}-\mathrm{C}_{14}(\pi) \rightarrow \mathrm{N}_{52}-\mathrm{N}_{53}\left(\pi^{*}\right) \\
\mathrm{Cl}_{4}(\mathrm{LPs}) \rightarrow \mathrm{C}_{56}-\mathrm{H}_{65}\left(\sigma^{*}\right) \\
\mathrm{C}_{27}-\mathrm{H}_{29}\left(\sigma^{*}\right) \leftarrow \mathrm{C}_{59}-\mathrm{O}_{62}(\pi)\end{array}$ & $\begin{array}{l}14.22 \\
2.80 \\
2.51 \\
2.22 \\
2.09 \\
1.88\end{array}$ \\
\hline A2 & -57.36 & -54.70 & -50.62 & -37.39 & $\begin{array}{l}\mathrm{C}_{35}-\mathrm{H}_{37}\left(\sigma^{*}\right) \leftarrow \mathrm{O}_{62}(\mathrm{LPs}) \\
\mathrm{C}_{38}-\mathrm{H}_{41}\left(\sigma^{*}\right) \leftarrow \mathrm{O}_{62}(\mathrm{LPs}) \\
\mathrm{N}_{12}(\mathrm{LP}) \rightarrow \mathrm{C}_{56}-\mathrm{H}_{65}\left(\sigma^{*}\right) \\
\mathrm{C}_{35}-\mathrm{H}_{37}\left(\sigma^{*}\right) \leftarrow \mathrm{N}_{53}(\mathrm{LP}) \\
\mathrm{C}_{55}-\mathrm{H}_{47}\left(\sigma^{*}\right) \leftarrow \mathrm{N}_{52}(\mathrm{LP}) \\
\mathrm{C}_{1}-\mathrm{C}_{3}(\pi) \rightarrow \mathrm{N}_{52}-\mathrm{N}_{53}\left(\pi^{*}\right)\end{array}$ & $\begin{array}{l}4.77 \\
4.60 \\
3.39 \\
2.89 \\
2.72 \\
2.13\end{array}$ \\
\hline A3 & -56.18 & -60.91 & -48.24 & -39.40 & $\begin{array}{l}\mathrm{C}_{13}-\mathrm{C}_{11}(\pi) \rightarrow \mathrm{C}_{50}-\mathrm{O}_{55}\left(\pi^{*}\right) \\
\mathrm{C}_{1}-\mathrm{C}_{3}(\pi) \rightarrow \mathrm{C}_{49}-\mathrm{C}_{57}\left(\pi^{*}\right) \\
\mathrm{C}_{1}-\mathrm{C}_{3}\left(\pi^{*}\right) \leftarrow \mathrm{N}_{52}-\mathrm{N}_{53}(\pi)\end{array}$ & $\begin{array}{l}4.35 \\
3.22 \\
2.22 \\
\end{array}$ \\
\hline A4 & -52.68 & -57.44 & -46.62 & -32.98 & $\begin{array}{l}\mathrm{C}_{1}-\mathrm{C}_{3}\left(\pi^{*}\right) \leftarrow \mathrm{N}_{52}(\mathrm{LP}) \\
\mathrm{C}_{38}-\mathrm{H}_{40}\left(\sigma^{*}\right) \leftarrow \mathrm{N}_{53}(\mathrm{LP}) \\
\mathrm{C}_{27}-\mathrm{H}_{28}\left(\sigma^{*}\right) \leftarrow \mathrm{C}_{58}-\mathrm{N}_{60}(\pi) \\
\mathrm{C}_{21}-\mathrm{H}_{23}\left(\sigma^{*}\right) \leftarrow \mathrm{C}_{59}-\mathrm{O}_{62}(\pi) \\
\mathrm{C}_{31}-\mathrm{H}_{32}\left(\sigma^{*}\right) \leftarrow \mathrm{C}_{59}-\mathrm{O}_{62}(\pi)\end{array}$ & $\begin{array}{l}5.98 \\
5.31 \\
3.81 \\
2.97 \\
2.09 \\
\end{array}$ \\
\hline A5 & -46.50 & -51.78 & -41.05 & -25.40 & $\begin{array}{l}\mathrm{C}_{3}-\mathrm{H}_{5}\left(\sigma^{*}\right) \leftarrow \mathrm{N}_{52}(\mathrm{LP}) \\
\mathrm{C}_{31}-\mathrm{H}_{32}\left(\sigma^{*}\right) \leftarrow \mathrm{O}_{62}(\mathrm{LPs}) \\
\mathrm{C}_{38}-\mathrm{H}_{39}\left(\sigma^{*}\right) \leftarrow \mathrm{O}_{62}(\mathrm{LPs}) \\
\mathrm{C}_{31}-\mathrm{H}_{32}\left(\sigma^{*} \leftarrow \mathrm{N}_{53}(\mathrm{LP})\right. \\
\mathrm{C}_{1}-\mathrm{C}_{3}(\pi) \rightarrow \mathrm{C}_{56}-\mathrm{H}_{63}\left(\sigma^{*}\right) \\
\mathrm{N}_{17}(\mathrm{LP}) \rightarrow \mathrm{N}_{52}-\mathrm{N}_{53}\left(\pi^{*}\right)\end{array}$ & $\begin{array}{l}8.87 \\
4.73 \\
4.35 \\
3.35 \\
2.59 \\
2.13\end{array}$ \\
\hline A6 & -45.44 & -48.71 & -42.24 & -24.93 & $\begin{array}{l}\mathrm{C}_{24}-\mathrm{H}_{25}\left(\sigma^{*}\right) \leftarrow \mathrm{O}_{62}(\mathrm{LPs}) \\
\mathrm{C}_{24}-\mathrm{H}_{25}\left(\sigma^{*}\right) \leftarrow \mathrm{C}_{59}-\mathrm{O}_{62}(\pi) \\
\mathrm{N}_{12}(\mathrm{LP}) \rightarrow \mathrm{C}_{56}-\mathrm{H}_{63}\left(\sigma^{*}\right) \\
\mathrm{N}_{12}-\mathrm{C}_{13}(\pi) \rightarrow \mathrm{C}_{56}-\mathrm{H}_{63}\left(\sigma^{*}\right) \\
\mathrm{C}_{42}-\mathrm{H}_{44}\left(\sigma^{*}\right) \leftarrow \mathrm{N}_{53}(\mathrm{LP})\end{array}$ & $\begin{array}{l}10.08 \\
6.69 \\
5.44 \\
3.81 \\
2.26\end{array}$ \\
\hline A7 & -43.93 & -43.77 & -38.32 & -24.97 & $\begin{array}{l}\mathrm{N}_{12}(\mathrm{LP}) \rightarrow \mathrm{N}_{61}-\mathrm{H}_{67}\left(\sigma^{*}\right) \\
\mathrm{N}_{12}-\mathrm{C}_{13}(\pi) \rightarrow \mathrm{N}_{61}-\mathrm{H}_{67}\left(\sigma^{*}\right) \\
\mathrm{Cl}_{4}(\mathrm{LPs}) \rightarrow \mathrm{C}_{50}-\mathrm{O}_{57}\left(\pi^{*}\right) \\
\mathrm{C}_{2}-\mathrm{C}_{6}\left(\pi^{*}\right) \leftarrow \mathrm{N}_{60}(\mathrm{LP})\end{array}$ & $\begin{array}{l}35.40 \\
5.48 \\
2.59 \\
1.92 \\
\end{array}$ \\
\hline A8 & -43.15 & -44.14 & -37.90 & -32.12 & $\begin{array}{l}\mathrm{N}_{12}(\mathrm{LP}) \rightarrow \mathrm{N}_{61}-\mathrm{H}_{67}\left(\sigma^{*}\right) \\
\mathrm{N}_{12}-\mathrm{C}_{13}(\pi) \rightarrow \mathrm{N}_{61}-\mathrm{H}_{67}\left(\sigma^{*}\right) \\
\mathrm{Cl}_{4}(\mathrm{LPs}) \rightarrow \mathrm{C}_{50}-\mathrm{O}_{57}\left(\pi^{*}\right)\end{array}$ & $\begin{array}{l}32.89 \\
7.32 \\
2.30\end{array}$ \\
\hline A9 & -40.71 & -41.80 & -39.30 & -21.53 & $\begin{array}{l}\mathrm{N}_{12}(\mathrm{LP}) \rightarrow \mathrm{N}_{61}-\mathrm{H}_{66}\left(\sigma^{*}\right) \\
\mathrm{N}_{12}-\mathrm{C}_{13}(\pi) \rightarrow \mathrm{N}_{61}-\mathrm{H}_{66}\left(\sigma^{*}\right) \\
\mathrm{C}_{42}-\mathrm{H}_{44}\left(\sigma^{*}\right) \leftarrow \mathrm{O}_{62}(\mathrm{LPs}) \\
\mathrm{C}_{22}-\mathrm{H}_{24}\left(\sigma^{*}\right) \leftarrow \mathrm{N}_{53}(\mathrm{LP})\end{array}$ & $\begin{array}{l}27.11 \\
14.98 \\
6.19 \\
2.64\end{array}$ \\
\hline A10 & -39.30 & -45.04 & -36.58 & -20.38 & $\begin{array}{l}\mathrm{N}_{12}(\mathrm{LP}) \rightarrow \mathrm{N}_{61}-\mathrm{H}_{67}\left(\sigma^{*}\right) \\
\mathrm{N}_{12}-\mathrm{C}_{13}(\pi) \rightarrow \mathrm{N}_{61}-\mathrm{H}_{67}\left(\sigma^{*}\right)\end{array}$ & $\begin{array}{l}32.89 \\
7.32 \\
\end{array}$ \\
\hline
\end{tabular}




\begin{tabular}{|l|l|l|l|l|l|l|}
\hline & & & & & $\mathrm{Cl}_{4}(\mathrm{LPs}) \rightarrow \mathrm{C}_{50}-\mathrm{O}_{57}\left(\pi^{*}\right)$ & 2.30 \\
\hline A11 & -36.73 & -40.98 & -36.36 & -14.89 & $\mathrm{Cl}_{4}(\mathrm{LPs}) \rightarrow \mathrm{N}_{61}-\mathrm{H}_{66}\left(\sigma^{*}\right)$ & 31.97 \\
& & & & $\mathrm{C}_{1}-\mathrm{H}_{8}\left(\sigma^{*}\right) \leftarrow \mathrm{O}_{62}(\mathrm{LPs})$ & 7.95 \\
& & & & $\mathrm{C}_{38}-\mathrm{H}_{41}\left(\sigma^{*}\right) \leftarrow \mathrm{O}_{62}(\mathrm{LPs})$ & 3.05 \\
& & & & $\mathrm{C}_{35}-\mathrm{H}_{37}\left(\sigma^{*}\right) \leftarrow \mathrm{C}_{59}-\mathrm{O}_{62}(\pi)$ & 2.97 \\
& & & & $\mathrm{C}_{28}-\mathrm{H}_{41}\left(\sigma^{*}\right) \leftarrow \mathrm{N}_{53}(\mathrm{LP})$ & 2.43 \\
\hline
\end{tabular}


Table 2. Binding energies BE and NBO second-order perturbation energies $\mathrm{E}(2)$ for CQB-TMZ complexes calculated with the $6-31+\mathrm{G}^{* *}$ basis set, all in $\mathrm{kJ} / \mathrm{mol}$.

\begin{tabular}{|c|c|c|c|c|c|}
\hline \multirow[t]{2}{*}{ Conformer } & \multicolumn{3}{|c|}{$\mathrm{BE}^{\mathrm{a}}$} & \multirow[t]{2}{*}{ CQ $\cdots \mathrm{TMZ}$} & \multirow[t]{2}{*}{$E(2)$} \\
\hline & M062X & B3LYP-D3 & MP2 & & \\
\hline B1 & $\begin{array}{l}-79.66 \\
3.14\end{array}$ & $\begin{array}{l}-81.48 \\
-9.50\end{array}$ & $\begin{array}{l}-80.20 \\
-0.16\end{array}$ & $\begin{array}{l}\mathrm{N}_{17}-\mathrm{H}_{18}\left(\sigma^{*}\right) \leftarrow \mathrm{O}_{62}(\mathrm{LPs}) \\
\mathrm{N}_{17}-\mathrm{H}_{18}\left(\sigma^{*}\right) \leftarrow \mathrm{C}_{59}-\mathrm{O}_{62}(\pi) \\
\mathrm{N}_{12}(\mathrm{LP}) \rightarrow \mathrm{H}_{64}-\mathrm{C}_{56}\left(\sigma^{*}\right) \\
\mathrm{C}_{21}-\mathrm{H}_{22}\left(\sigma^{*}\right) \leftarrow \mathrm{O}_{62}(\mathrm{LPs}) \\
\mathrm{C}_{9}-\mathrm{N}_{17}\left(\pi^{*}\right) \leftarrow \mathrm{N}_{52}-\mathrm{N}_{53}(\pi) \\
\mathrm{C}_{1}-\mathrm{C}_{3}\left(\sigma^{*}\right) \leftarrow \mathrm{C}_{49}-\mathrm{C}_{57}(\pi) \\
\mathrm{N}_{12}-\mathrm{C}_{13}(\pi) \rightarrow \mathrm{C}_{56}-\mathrm{H}_{64}\left(\sigma^{*}\right)\end{array}$ & $\begin{array}{l}32.34 \\
6.02 \\
5.14 \\
2.80 \\
2.43 \\
2.38 \\
2.18 \\
\end{array}$ \\
\hline B2 & $\begin{array}{l}-65.05 \\
17.76\end{array}$ & $\begin{array}{l}-74.43 \\
-2.45\end{array}$ & $\begin{array}{l}-52.00 \\
28.04\end{array}$ & $\begin{array}{l}\mathrm{N}_{34}(\mathrm{LP}) \rightarrow \mathrm{H}_{66}-\mathrm{N}_{61}\left(\sigma^{*}\right) \\
\mathrm{N}_{17}-\mathrm{H}_{18}\left(\sigma^{*}\right) \leftarrow \mathrm{O}_{62} \text { (LPs) } \\
\mathrm{C}_{3}-\mathrm{H}_{5}\left(\sigma^{*}\right) \leftarrow \mathrm{O}_{62} \text { (LPs) } \\
\mathrm{C}_{38}-\mathrm{H}_{40}\left(\sigma^{*}\right) \leftarrow \mathrm{N}_{61}(\mathrm{LP}) \\
\mathrm{C}_{45}-\mathrm{H}_{47}\left(\sigma^{*}\right) \leftarrow \mathrm{N}_{61}(\mathrm{LP})\end{array}$ & $\begin{array}{l}81.59 \\
53.80 \\
6.28 \\
4.06 \\
3.97 \\
\end{array}$ \\
\hline B3 & $\begin{array}{l}-47.54 \\
35.26\end{array}$ & $\begin{array}{l}-59.49 \\
12.49\end{array}$ & $\begin{array}{l}-41.80 \\
38.24\end{array}$ & $\begin{array}{l}\mathrm{N}_{17}-\mathrm{H}_{18}\left(\sigma^{*}\right) \leftarrow \mathrm{O}_{62} \text { (LPs) } \\
\mathrm{C}_{1}-\mathrm{C}_{3}\left(\sigma^{*}\right) \rightarrow \mathrm{H}_{66}-\mathrm{N}_{61}\left(\sigma^{*}\right) \\
\mathrm{C}_{3}-\mathrm{H}_{5}\left(\sigma^{*}\right) \leftarrow \mathrm{O}_{62} \text { (LPs) } \\
\mathrm{C}_{21}-\mathrm{H}_{22}\left(\sigma^{*}\right) \leftarrow \mathrm{N}_{53} \text { (LP) } \\
\mathrm{C}_{31}-\mathrm{H}_{32}\left(\sigma^{*}\right) \leftarrow \mathrm{N}_{52} \text { (LP) }\end{array}$ & $\begin{array}{l}24.02 \\
9.16 \\
7.45 \\
6.02 \\
4.31\end{array}$ \\
\hline B4 & $\begin{array}{l}-46.33 \\
36.47\end{array}$ & $\begin{array}{l}-47.02 \\
24.96\end{array}$ & $\begin{array}{l}-43.95 \\
36.08\end{array}$ & $\begin{array}{l}\mathrm{C}_{27}-\mathrm{H}_{29}\left(\sigma^{*}\right) \leftarrow \mathrm{O}_{55}(\mathrm{LPs}) \\
\mathrm{C}_{2}-\mathrm{C}_{6}(\pi) \rightarrow \mathrm{C}_{59}-\mathrm{O}_{62}\left(\pi^{*}\right)\end{array}$ & $\begin{array}{l}8.03 \\
1.76\end{array}$ \\
\hline B5 & $\begin{array}{l}-37.24 \\
45.57\end{array}$ & $\begin{array}{l}-50.08 \\
21.90\end{array}$ & $\begin{array}{l}-37.00 \\
43.04\end{array}$ & $\begin{array}{l}\mathrm{N}_{12}(\mathrm{LP}) \rightarrow \mathrm{H}_{66}-\mathrm{N}_{61}\left(\sigma^{*}\right) \\
\mathrm{C}_{13}-\mathrm{H}_{15}\left(\sigma^{*}\right) \leftarrow \mathrm{O}_{62}(\mathrm{LPs}) \\
\mathrm{C}_{45}-\mathrm{H}_{48}\left(\sigma^{*}\right) \leftarrow \mathrm{O}_{62}(\mathrm{LPs})\end{array}$ & $\begin{array}{l}73.17 \\
17.41 \\
2.76\end{array}$ \\
\hline B6 & $\begin{array}{l}-35.04 \\
47.76\end{array}$ & $\begin{array}{l}-47.01 \\
24.97\end{array}$ & $\begin{array}{l}-31.76 \\
48.27\end{array}$ & $\begin{array}{l}\mathrm{N}_{17}-\mathrm{H}_{18}\left(\sigma^{*}\right) \leftarrow \mathrm{N}_{60}(\mathrm{LP}) \\
\mathrm{N}_{17}(\mathrm{LP}) \rightarrow \mathrm{H}_{67}-\mathrm{N}_{61}\left(\sigma^{*}\right) \\
\mathrm{C}_{3}-\mathrm{H}_{5}\left(\sigma^{*}\right) \leftarrow \mathrm{N}_{60}(\mathrm{LP}) \\
\mathrm{C}_{21}-\mathrm{H}_{23}\left(\sigma^{*}\right) \leftarrow \mathrm{N}_{61}(\mathrm{LP})\end{array}$ & $\begin{array}{l}29.50 \\
29.50 \\
16.67 \\
3.97 \\
\end{array}$ \\
\hline B7 & $\begin{array}{l}-34.37 \\
48.44\end{array}$ & $\begin{array}{l}-45.88 \\
26.10\end{array}$ & $\begin{array}{l}-36.25 \\
43.79\end{array}$ & $\begin{array}{l}\mathrm{C}_{6}-\mathrm{H}_{7}\left(\sigma^{*}\right) \leftarrow \mathrm{N}_{60}(\mathrm{LP}) \\
\mathrm{N}_{12}(\mathrm{LP}) \rightarrow \mathrm{H}_{67}-\mathrm{N}_{61}\left(\sigma^{*}\right) \\
\mathrm{Cl}_{4}(\mathrm{LP} 2) \rightarrow \mathrm{H}_{68}-\mathrm{C}_{58}\left(\sigma^{*}\right)\end{array}$ & $\begin{array}{l}47.74 \\
26.74 \\
4.94 \\
\end{array}$ \\
\hline B8 & $\begin{array}{l}-21.73 \\
61.07\end{array}$ & $\begin{array}{l}-32.73 \\
39.25\end{array}$ & $\begin{array}{l}-19.94 \\
60.10\end{array}$ & $\begin{array}{l}\mathrm{N}_{12}(\mathrm{LP}) \rightarrow \mathrm{H}_{68}-\mathrm{N}_{58}\left(\sigma^{*}\right) \\
\mathrm{C}_{6}-\mathrm{H}_{7}\left(\sigma^{*}\right) \leftarrow \mathrm{N}_{60}(\mathrm{LP}) \\
\mathrm{Cl}_{4}(\mathrm{LP}) \rightarrow \mathrm{H}_{67}-\mathrm{N}_{61}\left(\sigma^{*}\right)\end{array}$ & $\begin{array}{l}30.00 \\
21.34 \\
5.73 \\
\end{array}$ \\
\hline B9 & $\begin{array}{l}-16.39 \\
66.41\end{array}$ & $\begin{array}{l}-25.16 \\
46.82 \\
\end{array}$ & $\begin{array}{l}-12.78 \\
67.26\end{array}$ & $\begin{array}{l}\mathrm{C}_{1}-\mathrm{H}_{8}\left(\sigma^{*}\right) \leftarrow \mathrm{O}_{62}(\mathrm{LPs}) \\
\mathrm{Cl}_{4}(\mathrm{LPs}) \rightarrow \mathrm{H}_{66}-\mathrm{N}_{61}\left(\sigma^{*}\right)\end{array}$ & $\begin{array}{l}25.19 \\
22.30\end{array}$ \\
\hline B10 & $\begin{array}{l}-5.65 \\
77.15\end{array}$ & $\begin{array}{l}-11.66 \\
60.32\end{array}$ & $\begin{array}{l}-2.98 \\
77.05\end{array}$ & $\begin{array}{l}\mathrm{Cl}_{4}(\mathrm{LPs}) \rightarrow \mathrm{H}_{67}-\mathrm{N}_{61}\left(\sigma^{*}\right) \\
\mathrm{C}_{2}-\mathrm{Cl}_{4}\left(\sigma^{*}\right) \leftarrow \mathrm{N}_{60}(\mathrm{LP})\end{array}$ & $\begin{array}{l}19.54 \\
2.59\end{array}$ \\
\hline B11 & $\begin{array}{l}-3.12 \\
79.69\end{array}$ & $\begin{array}{l}-8.36 \\
63.62\end{array}$ & $\begin{array}{l}-0.90 \\
79.13\end{array}$ & $\begin{array}{l}\mathrm{Cl}_{4}(\mathrm{LPs}) \rightarrow \mathrm{H}_{63}-\mathrm{C}_{56}\left(\sigma^{*}\right) \\
\mathrm{C}_{2}-\mathrm{Cl}_{4}\left(\sigma^{*}\right) \leftarrow \mathrm{N}_{52}(\mathrm{LP})\end{array}$ & $\begin{array}{l}10.04 \\
2.30\end{array}$ \\
\hline
\end{tabular}

aValues in italics refer to total energy relative to dimer A1 
Table 3. Comparison between B3LYP-D and B3LYP binding energies BE (kJ/mol) for CQA-TMZ complexes.

\begin{tabular}{|l|l|l|c|}
\hline Dimer & B3LYP-D3 & B3LYP & $\Delta$ BE $^{a}$ \\
\hline A1 & -48.55 & 37.69 & -86.14 \\
\hline A2 & -50.62 & 31.50 & -82.12 \\
\hline A3 & -48.24 & 47.05 & -95.29 \\
\hline A4 & -46.62 & 39.93 & -86.55 \\
\hline A5 & -41.05 & 38.06 & -79.11 \\
\hline A6 & -42.24 & 28.22 & -70.46 \\
\hline A7 & -38.32 & 33.30 & -71.62 \\
\hline A8 & -37.90 & 31.10 & -69.00 \\
\hline A9 & -39.30 & 12.75 & -52.05 \\
\hline A10 & -36.58 & 39.66 & -76.24 \\
\hline A11 & -36.36 & 20.07 & -56.43 \\
\hline
\end{tabular}

${ }^{\mathrm{a}} \triangle \mathrm{BE}=\mathrm{B} 3 \mathrm{LYP}-\mathrm{D} 3-\mathrm{B} 3 \mathrm{LYP}$

Table 4. Comparison between B3LYP-D and B3LYP binding energies BE (kJ/mol) for CQBTMZ complexes.

\begin{tabular}{|l|r|r|r|}
\hline Conformer & \multicolumn{1}{|c|}{ B3LYP-D3 } & \multicolumn{1}{c|}{ B3LYP } & \multicolumn{1}{c|}{$\Delta \mathrm{BE}$} \\
\hline B1 & 81.48 & 1.05 & 80.43 \\
\hline B2 & 74.43 & 25.74 & 48.69 \\
\hline B3 & 59.49 & 10.99 & 48.50 \\
\hline B4 & 47.02 & -24.77 & 71.79 \\
\hline B5 & 50.08 & 18.93 & 31.15 \\
\hline B6 & 45.88 & 5.80 & 43.08 \\
\hline B7 & 47.01 & -9.45 & 56.46 \\
\hline B8 & 32.73 & 14.22 & 18.51 \\
\hline B9 & 25.16 & 12.95 & 12.21 \\
\hline B10 & 11.66 & 1.64 & 9.62 \\
\hline B11 & 8.36 & -0.54 & 8.90 \\
\hline
\end{tabular}



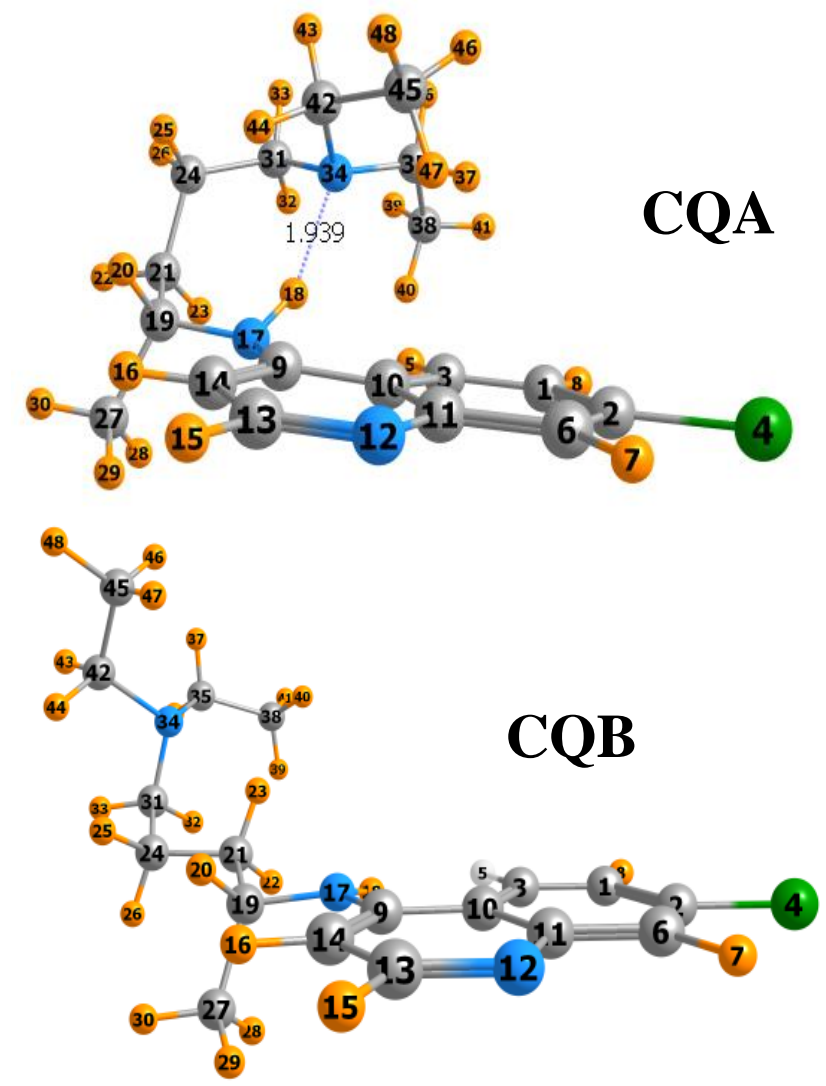

Fig 3. Structures of chloroquine's global minimum CQA, and secondary minimum CQB, including atomic numbering scheme. 

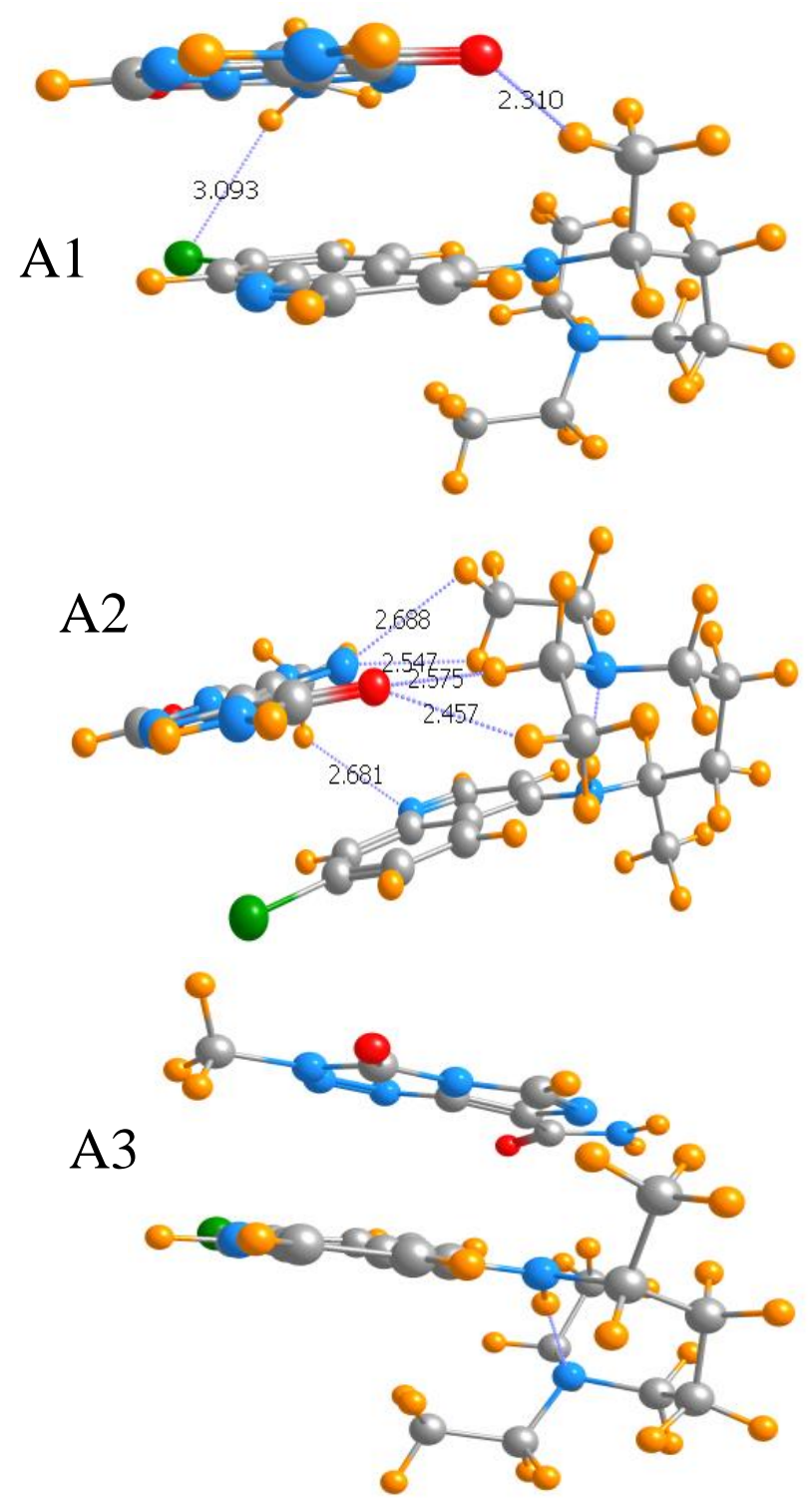

Fig 4. Structures of three most stable minima of CQA with TMZ 

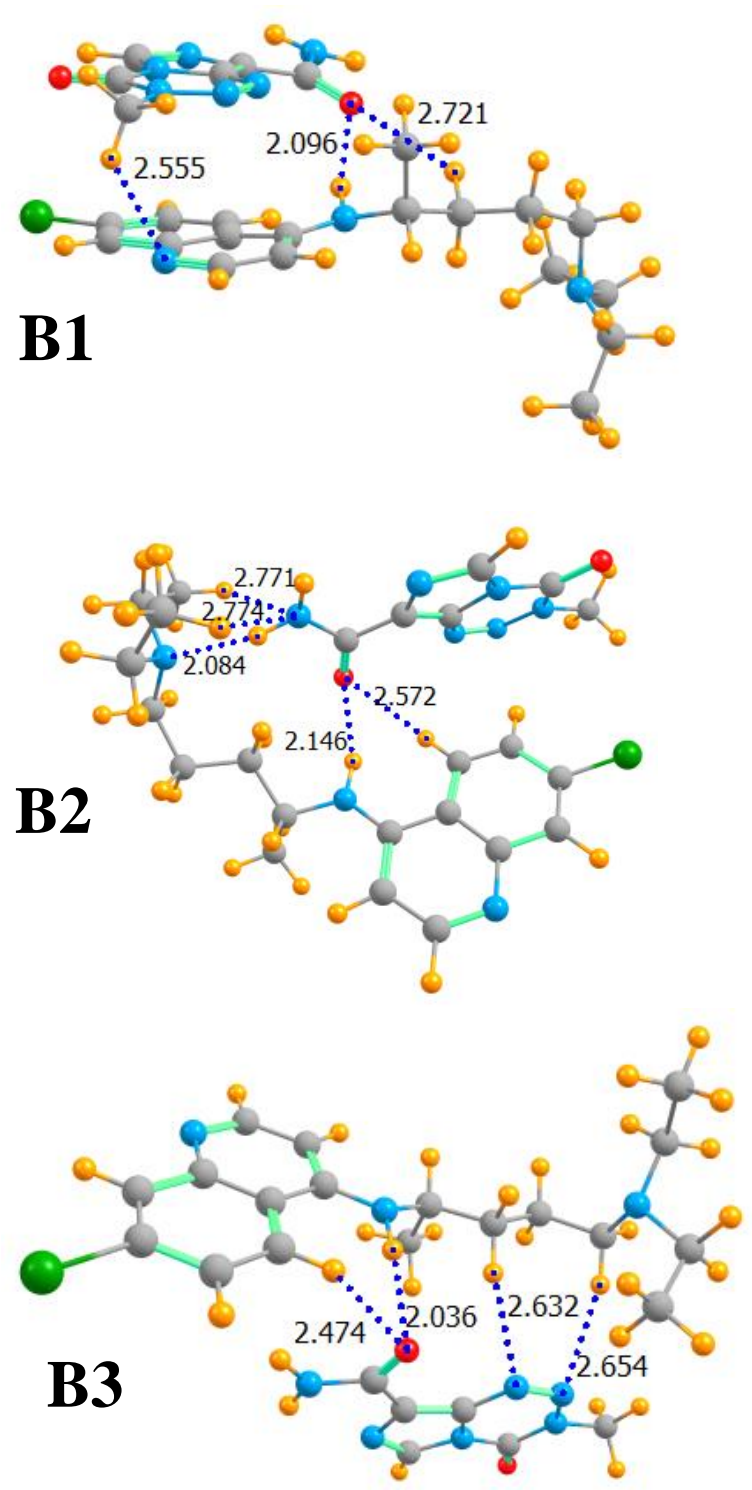

Fig 5. Structures of three most stable minima of CQB with TMZ 

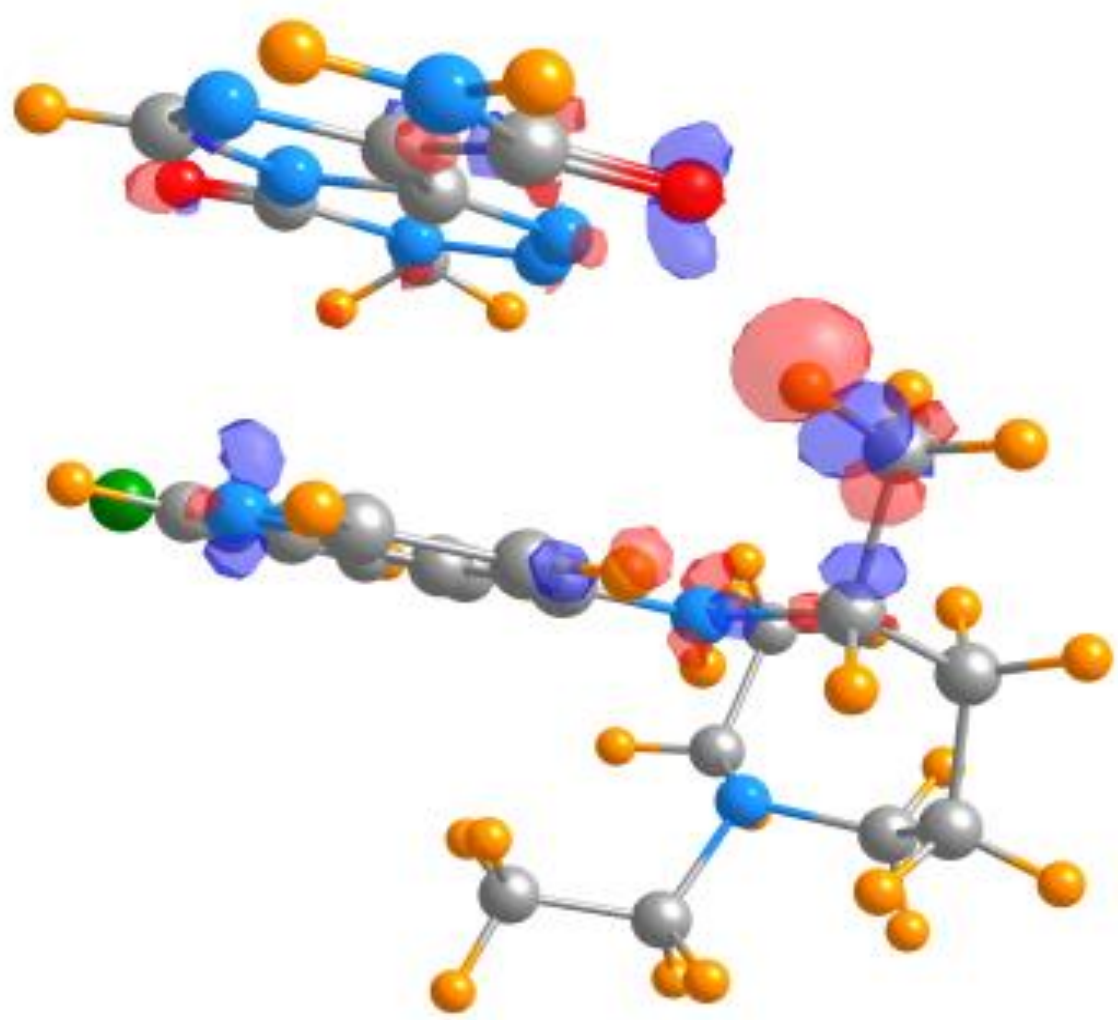

Fig 6. Electron density shifts that accompany the formation of the A1 dimer. Blue and red regions respectively represent gains and losses of density, at the \pm 0.0015 au contour. 


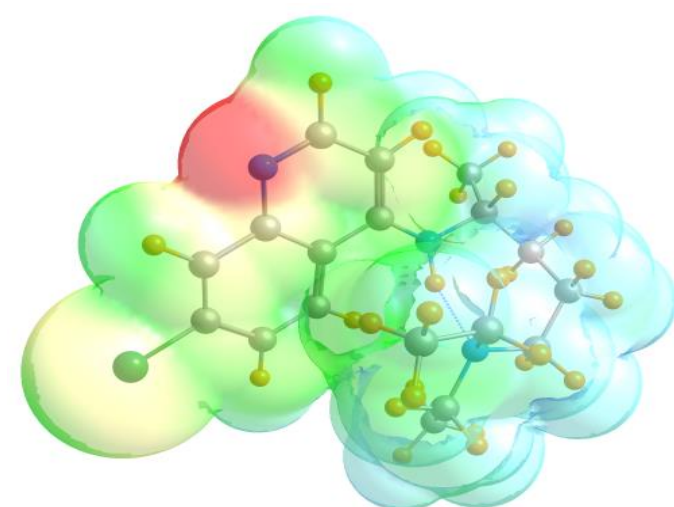

a) CQA

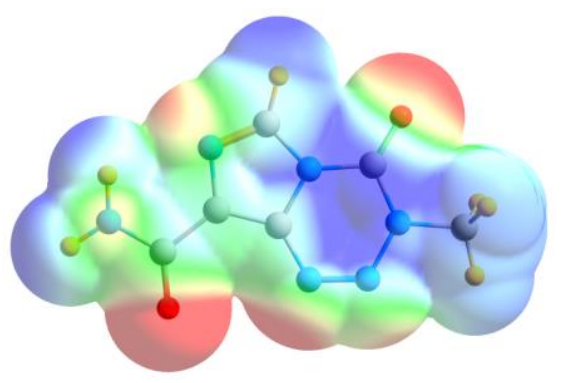

b) $\mathrm{TMZ}$

Fig 7. Molecular electrostatic potential surrounding a) CQA and b) TMZ on surface representing 1.5 times the van der Waals radius of each atom. Blue color indicates a potential of $+0.05 \mathrm{au}$, and red corresponds to -0.05 . 


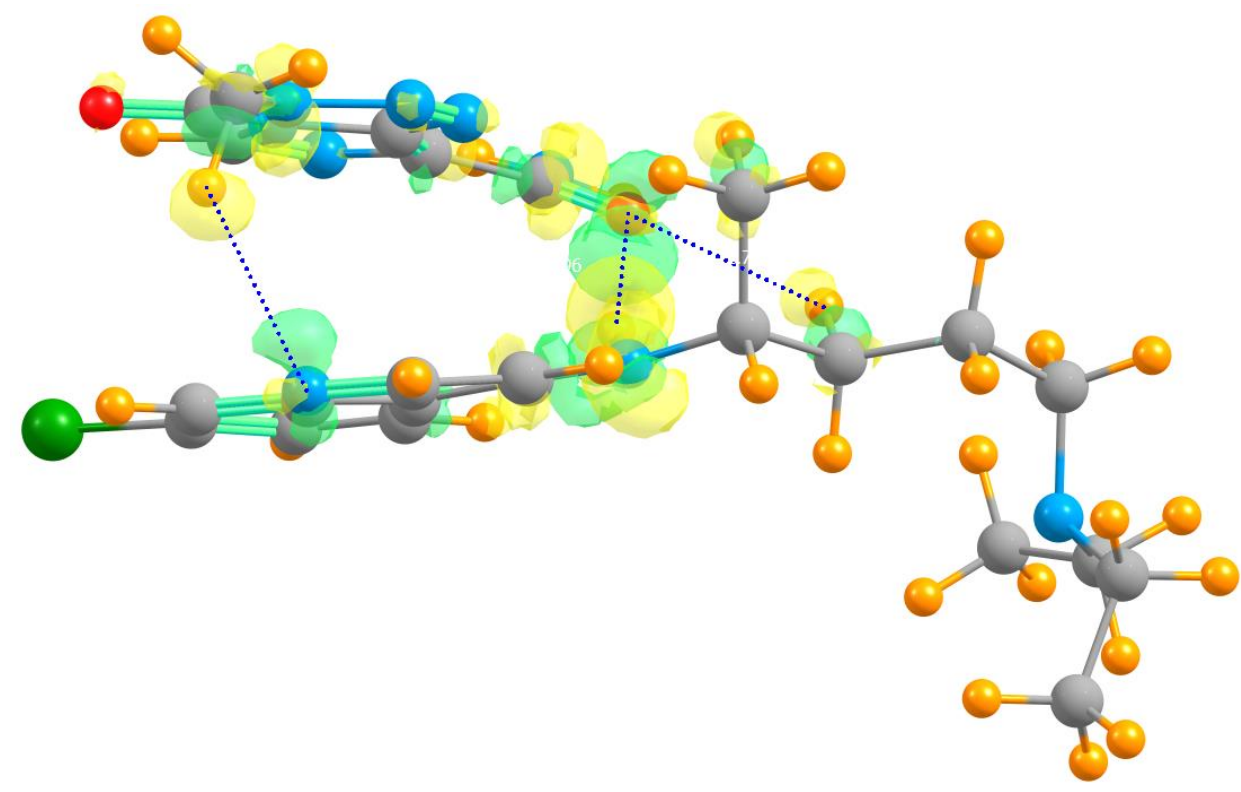

Fig 8. Electron density shifts that accompany the formation of the B1 dimer. Green and yellow regions respectively represent gains and losses of density, at the \pm 0.0015 au contour. 